\title{
Performance Evaluation of Private Commercial Banks of Bangladesh: A Trend Analysis
}

\author{
Omar Faruque*, Md. Shahinoor Rahman \\ Assistant Professor, Department of Accounting and Information Systems, Begum Rokeya University, Rangpur, BANGLADESH \\ *E-mail for correspondence: faruque1712@gmail.com
}

https://doi.org/10.18034/abr.v8i1.45

\begin{abstract}
The study revealed the trend analysis of the private commercial banks and given an overview of the performance of private commercial banks of Bangladesh. Nowadays, the banking sector is the "lifeblood" of all economic activity. The study is empirical. To get the proper understanding about the trend of different variables such as, investment loan \& advancement, total asset, total liability, total equity, profit after tax, return on investment, return on asset, and return on equity from 2013 to 2017 the sample was extracted from the scheduled commercial banks. The result shows that the banking system of Bangladesh is not running at a normal pace. The index of the various variable of PCBs has progressed in some years, but again it has been delayed for the next time. The ROI and the ROA result show the best output in 2014 and the worst in 2017. On the other side, the best return on equity shows in 2014, but it is in the lowest position in 2015 because of a sudden increase in an equity position. The trend of profit after tax is like a wave. In 2014 and 2016 it is increased than the last year. On the other hand, in 2013, 2015 \& 2017 it is decreased in comparison to the previous year. The data shows that the PAT is rotated within 15,000 to 20000 million taka. It is studied that, the growth and development, as well as the performance trend, is not rhythmic. PCBs should get the proper rhythm of their development, and for the development of the state.
\end{abstract}

Key words: Bank, Commercial Bank, Performance Evaluation, Earning per Share, Return on Asset

\section{INTRODUCTION}

The backbone of the economic development of a country is the sound banking system. The bank is the most important financial institution of a country. It is an essential organ of every state. The banking sector is always deemed as a most important sector for the economy. This sector is for the proper functioning of a county. Nowadays, it is the "lifeblood" of all economic activity. It provides the deposit and loan facility to the people, corporations, and state. Bank leads to prepare the financial policy of a country and implement that. To meet the financial needs of the people and corporation PCBs is a must. To improve the economic conditions of a nation, the development of the banking sector is an early requirement.

The Bank is one of the important economic institutions of a state. A sustainable banking system ensures the sustainable development of a country. A bank ensures some important economic facilities for the whole nation. So, today the bank is very important for the economic and socio-economic development in Bangladesh. The importance of financial institution is to realize by the state for their uninterrupted economic development. It is an important issue for both developed and developing countries. A developed country always seeks the appropriate way to meet their capital requirements.

The banking industry in Bangladesh started its journey with six nationalized commercialized banks, two stateowned specialized banks, and three foreign Banks. In the 1980's banking industry achieved significant expansion with the entrance of private banks. Now, banks in Bangladesh are primarily of two types: scheduled banks and non-scheduled banks. Bangladesh Bank empowered by the Bangladesh Bank Order, 1972 and Bank Company Act, 1991 and controls fifty seven scheduled banks in Bangladesh. There are six SOCBs which are fully or majorly owned by the Government of Bangladesh; two specialized banks are now operating which were established for specific objectives like agricultural or industrial development. There are forty private commercial banks which are majorly owned by the private entities. PCBs can be categorized into two 
categories conventional PCBs and Islami shariah based PCBs. There are nine Foreign Commercial Banks (FCBs) are operating in Bangladesh as the branches of the banks which are incorporated in abroad. There are now six nonscheduled banks in Bangladesh. There are thirty-four FIs are also operating in Bangladesh (Bangladesh Bank 2018, https://www.bb.org.bd/fnansys/bankfi.php). $\quad 70.18 \%$ schedule banks in Bangladesh are private commercial banks (PCBs). So, it is an undutiful statement that these PCBs are the lifeblood of Bangladesh. So the development of the country highly depends on the development of these banks. Their performance encourages the performance of a state. So, for the growth and development of Bangladesh is depends on the performance of PCBs development.

\section{LITERATURE REVIEW}

Chowdhury (2009) tried to analyze the development and growth of Selected Private Commercial Banks of Bangladesh. It is observed that all the selected private commercial banks can achieve stable growth of branches, employees, deposits, loans, and advances, net income, earnings per share during the period of 2002-2006.

Chowdhury and Islam (2007) stated that deposits and loan advances of Nationalized Commercial Banks (NCBs) are less sensitive to interest changes than those of Specialized Banks (SBs). So SBs should not make an abrupt change in lending or deposit rates by following the NCBs. If NCBs change their lending or deposit rates, their deposits or loans and advances will be affected less than those of SBs. Moreover, deposits of NCBs have higher volume and higher volatility than those of SBs. On the other hand, loans advances of NCBs show a higher volume and higher volatility than those of SBs.

Siddique and Islam (2001) pointed out that, the commercial banks, as a whole are performing well and contributing to the economic development of the country. The average profitability of all Bangladeshi Banks collectively was 0.09\% during 1980 to 1995 which means that a profit of Tk.0.09 was earned by utilizing assets of Tk.100 in every aspect of profit; banking sector contributes the national economy as well as the individual organization.

Almazari (2011) in his study measured the financial performance of some selected Jordanian commercial banks for the period 2005-2009. The study used simple regression analysis. In the study, bank size, asset management, and operational efficiency were taken as an independent variable, and the dependent variable was taken as financial performance represented by; return on assets and interest income. The study concluded that banks with higher total deposits, credits, assets, and shareholders' equity does not always result in better profitability performance.

Nimalathasan (2008) undertook a comparative study of the financial performance of the banking sector in
Bangladesh using the CAMELS rating system. The study was done on 6562 Branches of 48 Banks in Bangladesh for the financial year 1999-2006. The study revealed that out of 48 banks, three banks were rated 01 or Strong, 31 banks were rated 02 or satisfactory, seven banks were rated 03 or Fair, five banks were rated 04 or Marginal and, two banks obtained 05 or unsatisfactorily rating. 1 Nationalized Commercial Bank (NCB) had unsatisfactorily rating and other 3 NCBs had the marginal rating.

Dey and Kabir (2012) reveals that all executives of the three sample banks have placed high emphasis on knowledge of banking rules and regulations, writing skill and knowledge about the bank's products, services and polices, appearance and dress code, creativity \& innovative ideas, attendance and punctuality, personality, discipline, capacity to taking independent decision, perseverance, ability to adopt in changing circumstances, attitude / temperament, human quality, dynamic / proactive leadership, Initiative, Drive and Enthusiasm, Ability to negotiate, Power of Judgment in decision making, Ability to plan, organize and supervise work, Sense of responsibility of assigned jobs and commitment to work, Managing capabilities including crisis Management, marketing ability, ability to collect deposits as per set target, ability to market company's banking products to existing corporate and retail customers, ability to motivate existing customers to pay the dues in time, ability to enhance business of both clients and the bank, ability to recover the outstanding loans of the classified accounts, customer client Relationship/ dealing with bank's client and problemsolving ability in customer need satisfaction.

Malhotra et al. (2011) analyzes the performance of commercial banks in India during the period 2005 to 2009. This period covers the pre-credit crisis and the crisis period. Specifically, the paper examines the behavior of profitability, cost of intermediation, efficiency, soundness of the banking system, and industry concentration for public and private sector Indian commercial banks.

Haque (2013) attempts primarily to measure the financial performance of some selected private commercial banks in Bangladesh for the period 2006-2011 and to identify whether any relationship exists between a bank's years of operation and its performance. The study concluded that there is no specific relationship between the generation of banks and its performance.

Uddin and Bristy (2014) evaluates the performance of selected private commercial banks in Bangladesh. In the study, best efforts have been put on evaluating the performance. The growing pattern of branches, employees, deposits, loans, and advances, classified loan, net income and earnings per share of selected private commercial banks have been considered to analyze the performance evaluation of the selected private commercial banks.

Anbalagan and Gurusamy (2013) attempts to analyze the data with the help of mean, standard deviation, a coefficient of variation and ratio. The scope of the study is limited to 
scheduled commercial banks (SCBs) in India. The scheduled commercial banks include public sector banks (PSBs), private sector banks (PvtSBs) and foreign banks (FBs). The period of the study is five years, starting from 2007-08 to 2011-12.

Alemu and Aweke (2017) analyzes the overall performance of private commercial banks in Ethiopia using a CAMEL rating approach. In this study, the financial performance of six sampled private banks was measured using the audited financial reports of 10 years period (2007-2016). The Novel feature of this study was the inclusion of more explanatory variables, which were not used by the average researchers, i.e., a fixed asset to total assets, net profit per employee, total deposit per no. of branches, total loan per no. of branches, measurements.

Alkhatib and Harsheh (2012) examined the financial performance of five Palestinian commercial banks using three indicators: Internal-based, Market-based and Economic-based performance measures. Return on Assets, Tobin's Q model, and Economic Value add methods have been used for measuring these three indicators. Correlation and multiple regression analysis have been applied in this study to analyze the influence of bank size, credit risk, operational efficiency and asset management on financial performance and to create a good-fit regression model to predict the future financial performance of these banks. As findings, the study has indicated that there is a significant impact of bank size, credit risk, operational efficiency and asset management on the financial performance of Palestinian commercial banks.

\section{ObJectives OF THE Study}

The main objective of the study is to give an overview of the performance of private commercial banks of Bangladesh. The study also includes some specific Table 2: Value of different variables over the time objectives. The study also attempts to introduce the conditions of banking business in Bangladesh, drawing a picture of performance evaluation of the banking industry of Bangladesh, and getting a present trend of the performance of this industry.

\section{Methodology}

The study is empirical. To compute the trend over the time of the private commercial banks of Bangladesh, a sample of 10 private commercial banks are taken from the period 2013 to 2017. The sample was extracted from the scheduled commercial banks. To get the proper understanding about the trend different variables such as, investment loan \& advancement, total asset, total liability, total equity, profit after tax, return on investment, return on asset, and return on equity for sample years is calculated. Out of 57 PCBs of Bangladesh, 40 PCBs are taken as a sample. The data are collected from the annual report of the specific banks. The following table:1 shows the sample details.

Table 1: Sample detail

\begin{tabular}{|c|c|c|c|c|c|c|}
\hline Sumple & $\begin{array}{l}\text { Total } \\
\text { Benki. }\end{array}$ & $\begin{array}{c}\text { Schedtuled } \\
\text { Banka }\end{array}$ & $\begin{array}{c}\text { No. of } \\
\text { cornpanies } \\
\text { taken as sample }\end{array}$ & $\begin{array}{c}\% \text { of total } \\
\text { banks taken } \\
\text { nat nampiple }\end{array}$ & $\begin{array}{l}\text { \%o of scheduled } \\
\text { banks taken } \\
\text { as sample }\end{array}$ & $\begin{array}{l}\text { No, of yeurs of } \\
\text { sample banks }\end{array}$ \\
\hline $\begin{array}{c}\text { Private } \\
\text { Commercial } \\
\text { Banka }\end{array}$ & 63 & 57 & 10 & 15.87 & 1754 & 5 \\
\hline
\end{tabular}

FINDINGS AND DISCUSSION

Table 2 highlights the position and performance of PCBs of Bangladesh from 2013 to 2017. The appendix shows the detail of the data analysis. By the data, three graphs for trend are prepared. The following table shows the total of investment, loan \& advancement, total asset, total liability and total yearly equity position of the sample banks for the said period.

\begin{tabular}{|c|c|c|c|c|c|c|c|c|c|}
\hline & Investment & $\begin{array}{c}\text { Loan \& } \\
\text { advancement }\end{array}$ & $\begin{array}{c}\text { Total } \\
\text { asset }\end{array}$ & $\begin{array}{c}\text { Total } \\
\text { liability }\end{array}$ & $\begin{array}{c}\text { Total } \\
\text { equity }\end{array}$ & $\begin{array}{c}\text { Profit after } \\
\text { tax (PAT) }\end{array}$ & $\begin{array}{c}\text { Return on } \\
\text { Investment } \\
\text { (ROI) }\end{array}$ & $\begin{array}{c}\text { Return on } \\
\text { asset (ROA) }\end{array}$ & $\begin{array}{c}\text { Return on } \\
\text { equity (ROE) }\end{array}$ \\
\hline 2013 & 430096.68 & 963,092 & 1558431.2 & 1061778.3 & 129731.42 & 15544.82 & 3.61 & 1.00 & 11.98 \\
\hline 2014 & 418306.12 & $1,119,720$ & 1622997.8 & 1221349.4 & 150664.46 & 19035.97 & 4.55 & 1.17 & 12.63 \\
\hline 2015 & 465886.2 & $1,169,903$ & 1893389.8 & 1419075.2 & 291809.01 & 18224.70 & 3.91 & 0.96 & 6.25 \\
\hline 2016 & 493698.78 & $3,358,516$ & 2134022.6 & 1661381.9 & 171023.38 & 19138.27 & 3.88 & 0.90 & 11.19 \\
\hline 2017 & 499119.27 & $1,753,081$ & 2443178 & 1827025.6 & 182163.31 & 16453.59 & 3.30 & 0.67 & 9.03 \\
\hline $\begin{array}{c}\text { Grand } \\
\text { Total }\end{array}$ & 2307107.1 & 8364313.2 & 9652019.3 & 7190610.3 & 925391.58 & 88397.35 & 3.83 & 0.92 & 9.55 \\
\hline
\end{tabular}

Source: Constructed from the annual report of the sample banks

The data shows that the investment was reduced by $97.26 \%$ in 2014 , but in 2015 it is increased by $8.32 \%$ and $11.37 \%$ in comparison to the year 2013 and 2014 respectively. On the other hand, loan \& advancement, total asset, and total liability are increased in every year. The position of total equity is also increasing in a normal range, but in 2015 it is doubled by the previous year, though in the next year it is also decreased and followed the expected increasing rate.
Return on Assets (ROA) is an indicator of efficient management of assets to generate the earnings. It shows the profitable of a company is relative to the total assets. Return on investment (ROI) measures the output which is generated by an investment. It is expressed in percentage. It shows the profitability and can be compared with other of the corporation. The ROI and the ROA result show the best output in 2014 and the worst output in 2017. 


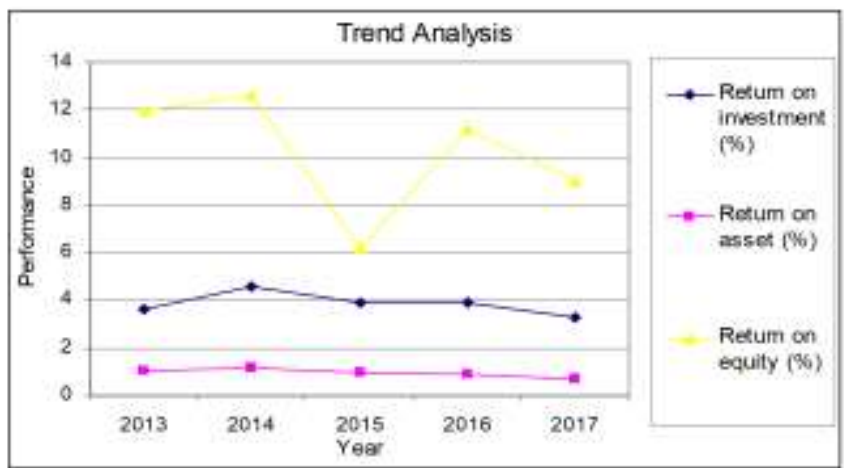

Graph 1: Trend analysis of ROI, ROA, ROE

Source: Constructed by the authors based on the annual report data of the sample banks

Return on equity (ROE) is a net return shown as a percentage of the equity of the shareholder. ROI reveals how much profit a company generates against the money invested by the shareholders. On the other side, the best return on equity shows in 2014, but it is in the lowest position in 2015 because of a sudden increase in the equity position.

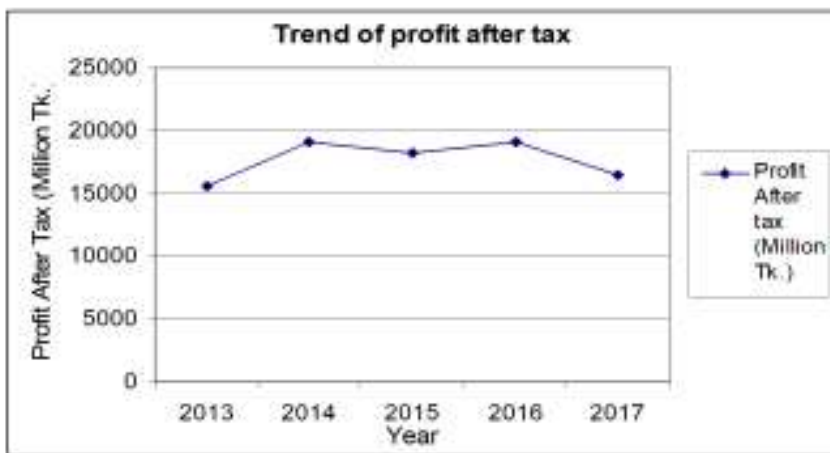

Graph 2: Trend profit after tax

Source: Constructed by the authors based on the annual report data of the sample banks

The trend of profit after tax is like a wave. In 2014 and 2016 it is increased than the last year. On the other hand, in 2013, 2015 \& 2017 it is decreased in comparison to the previous year. The data shows that the PAT is rotated within 15,000 to 20,000 million taka.

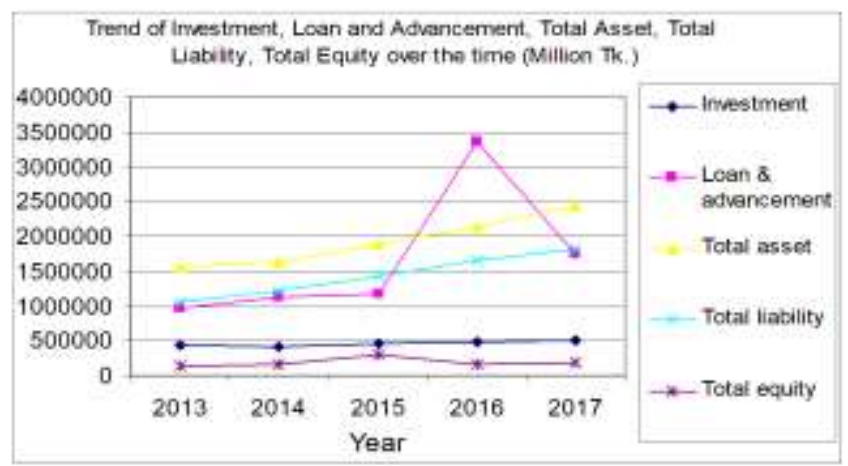

Graph 3: Trend of investment, loan and advancement, total asset, total liability, total equity

Source: Constructed by the authors based on the annual report data of the sample banks
The graph 3 shows the trend of investment, loan, and advancement, total asset, total liability, and total equity from 2013 to 2017. The trend shows that the loan and advancement position is increased abnormally in 2016. The total asset and liability position is grown at a constant speed. The total equity position was height in 2015. The result shows that over the time the investment position was gradually increased.

\section{CONCLUSION}

The banking system is changing our lives every day. The development of the banking systems progresses the economic condition of a country. In this study, the present condition of the PCBs of Bangladesh has been shown. The result is that the banking system of Bangladesh is not running at a pace. The index of the various variable of PCBs has progressed in some years, but again it has been delayed for the next time. It is studied that, there are limitation in controlling of PCBs by the authorities. For the absence of the proper monitoring of PCBs, the growth and development, as well as the performance trend, are not rhythmic. If the PCBs keep the rhythm of their development, the state will get the right economic way.

\section{REFERENCES}

Ahmed, A. A. (2011). Financial Performance Evaluation of Some Selected Jordanian Commercial Banks. International Research Journal of Finance and Economics, 6(4), 50-63.

Ahmed, F. (1995) Performance of Commercial Banks in Bangladesh-A Note on Current trends. Journal of the Institute of Bankers, Bangladesh, Vol. 36 -41, December 1992-June 1995.

Al Shammari, M., and Salimi, M. (1998). Modeling the operating efficiency of banks, A parametric methodology. Journal of Logistic Information Management, Vol. 11.

Alemu. M., \& Aweke. M., (2017), 'Financial Performance Analysis of Private Commercial Banks of Ethiopia: Camel Ratings', International Journal of Scientific and Research Publications, 7(10), Pp 367-395

Ali, K., Akhtar, M. \& Ahmed, H. (2011). Bank-Specific and Macroeconomic Indicators of Profitability -Empirical Evidence from the Commercial Banks of Pakistan. International Journal of Business and Social Science, 2(6), 235-242.

Alkhatib. A. \& Harsheh. M., (2012), 'Financial Performance of Palestinian Commercial Banks', International Journal of Business and Social Science, 3(3), Pp 175-184

Almazari, A. A. (2011), 'Financial Performance Evaluation of Some Selected Jordanian Commercial Banks' International Research Journal of Finance and Economics, Issue 68, Pp: 50-63.

Anbalagan, M. \& Gurusamy, M. (2013), Performance Evaluation of scheduled commercial Banks in India, Market Survey, 12-16

Arzu, T. \& Gokhan, G. (2005). Asset and Liability management in financial crises. The Journal of Risk Finance, 6(2), 35-49.

Avkiran, N. K. (1997). Models of retail performance for bank branches: predicting the level of key business drivers, International Journal of Bank Marketing, Vol. 15, No. 6.

Chowdhury, A., (2002). Politics, Society and Financial Sector Reform in Bangladesh. International Journal of Social Economies, 29(12), 963 - 988. 
Chowdhury, H. A., and Islam, M. S. (2007). Interest Rate Sensitivity of Loans and Advances: A Comparative Study between Nationalized Commercial Banks (NCBs) and specialized Banks (SBs). ASA University Review, Vol.1, No.1.

Chowdhury, T. A., \& Ahmed, K. (2009), Performance Evaluation of Selected Commercial Banks in Bangladesh, International Journal of Business and Management, 4(4), 86-97. Accessed from http:/ / citeseerx.ist.psu.edu/viewdoc/download?doi=10.1. 1.665.1124\&rep=re

Dey. S. \& Kabir, M. A. (2012), Performance Analysis through CAMEL Rating: A Comparative Study of Selected Private Commercial Banks in Bangladesh, Journal of Politics $\mathcal{E}$ Governance, 1(2/3), 16-25

Dhanabhakyam M. \& Kavitha, M. (2012). Financial Performance of selected Public sector banks in India. International Journal of Multidisciplinary Research, 2(1), pp 255- 269.

Haque, S., (2013), 'The Performance Analysis of Private Conventional Banks: A Case Study of Bangladesh', IOSR Journal of Business and Management (IOSR-JBM), 12(1), Pp: 19-25

Hossain, M. K., and Bhuiyan, R. H. (1990). Performance Dynamics of Nationalized Commercial Banks in Bangladesh- The Case of Sonali Bank. Journal of Business Studies, University of Dhaka, Vol. XI, No. 1.

Islam, M. A. \& Siddiqui, M. H. (2014), Performance Evaluation of the Banking Sector in Bangladesh: A Comparative Analysis, Business and Economic Research, 4(1)

Islam, M. S. (2007), Interest sensitivity of loans and advances: A competitive study between nationalized commercial banks and specialized commercial banks, ASA University review, 1(1), 124141.

Kalpana, B., \& Rao, T.V. (2017), Role of Commercial Banks in the Economic Development of India, International Journal of Management and Applied Science, 4(3), accessed from http:/ / www.iraj.in/journal/journal_file/journal_pdf/14358-14982087631-4.pdf

Karim, R. A., \& Alam, T., (2013) An Evaluation of Financial Performance of Private Commercial Banks in Bangladesh: Ratio Analysis, Journal of Business Studies Quarterly, 5(2), 65-77.

Malhotra, D. K., Poteau, R., \& Singh, R., (2011), 'Evaluating the Performance of Commercial Banks In India', Asia Pacific Journal of Finance and Banking Research, 5(5).

Nimalathasan, B. (2008), 'A Comparative Study of Financial Performance of Banking Sector in Bangladesh - An Application of CAMELS Rating System', Annals of University of Bucharest, Economic and Administrative series, nr. 2, Pp: 141-152

Siddique, S. H., and Islam, A. F. M. M. (2001). Banking Sector in Bangladesh: Its Contribution and Performance. Journal of Business Research, Jahangirnagar University, Vol. 3.

Siddiqui, M. A., \& Shoaib, A. (2011). Measuring performance through capital structure: Evidence from Banking Sector of Pakistan. African Journal of Business Management, 5(5), 1871-1879.

Uddin. M. R., \& Bristy. J. F., (2014), 'Evaluation of Some Private Commercial Banks in Bangladesh from Performance Perspectives', International Journal of Managing Value and Supply Chains (IJMVSC), 5(4)

\section{APPENDIX}

Detail sample data

\begin{tabular}{|c|c|c|c|c|c|c|c|c|c|c|}
\hline Banks & Year & $\begin{array}{l}\text { Investment } \\
\text { (Million Tk) }\end{array}$ & $\begin{array}{c}\text { Loan \& } \\
\text { Advancement } \\
\text { (Million Tk) }\end{array}$ & $\begin{array}{c}\text { Total Asset } \\
\text { (Million Tk) }\end{array}$ & $\begin{array}{c}\text { Total Liability } \\
\text { (Million Tk) }\end{array}$ & $\begin{array}{l}\text { Total Equity } \\
\text { (Million Tk) }\end{array}$ & $\begin{array}{c}\text { Profit } \\
\text { after tax } \\
\text { (Million } \\
\text { Tk) } \\
\end{array}$ & $\begin{array}{l}\text { Return on } \\
\text { investment } \\
(\%)\end{array}$ & $\begin{array}{l}\text { Return on } \\
\text { asset (\%) }\end{array}$ & $\begin{array}{l}\text { Return on } \\
\text { equity }(\%)\end{array}$ \\
\hline \multirow{5}{*}{$\begin{array}{l}\text { AB Bank } \\
\text { Limited }\end{array}$} & 2017 & 45,749 & 229,647 & 314,565 & 314,565 & 22,771 & 30 & 0.07 & 0.01 & 0.13 \\
\hline & 2016 & 46,667 & $2,118,769$ & 314,836 & 314,836 & 23,114 & 1,305 & 2.80 & 0.41 & 5.65 \\
\hline & 2015 & 32,559 & 209,725 & 285,010 & 285,010 & 22,792 & 1,270 & 3.90 & 0.45 & 5.57 \\
\hline & 2014 & 30,000 & 177,571 & 246,331 & 246,331 & 19,314 & 1,260 & 4.20 & 0.51 & 6.52 \\
\hline & 2013 & 28,676 & 140,121 & 208,006 & 208,006 & 16,940 & 1,011 & 3.53 & 0.49 & 5.97 \\
\hline \multirow{5}{*}{$\begin{array}{c}\text { Al- } \\
\text { Arafah } \\
\text { Islami } \\
\text { Bank }\end{array}$} & 2017 & $235,905.23$ & $232,614.23$ & $319,255.29$ & 293734.61 & $22,520.68$ & $3,169.50$ & 1.34 & 0.99 & 14.07 \\
\hline & 2016 & $196,519.38$ & $189,169.39$ & $272,900.07$ & $248,562.56$ & $21,337.48$ & $3,349.40$ & 1.70 & 1.23 & 15.70 \\
\hline & 2015 & $162,503.14$ & $156,466.15$ & $229,106.66$ & $206,870.58$ & $19,236.07$ & $2,465.88$ & 1.52 & 1.08 & 12.82 \\
\hline & 2014 & $146,740.37$ & $192,279.48$ & $210,439.01$ & $192,279.48$ & $18,159.52$ & 2,324.95 & 1.58 & 1.10 & 12.80 \\
\hline & 2013 & $125,715.39$ & 156457.54 & $293,734.61$ & $157,070.45$ & $16,091.17$ & $2,276.68$ & 1.81 & 0.78 & 14.15 \\
\hline \multirow{3}{*}{$\begin{array}{c}\text { Bank } \\
\text { Asia } \\
\text { Limited }\end{array}$} & 2017 & $27,545.82$ & $197,504.14$ & $288,996.64$ & 288,977 & $21,054.49$ & $2,047.53$ & 7.43 & 0.71 & 9.72 \\
\hline & 2016 & $39,365.21$ & $163,609.78$ & $253,195.70$ & 253,195 & $19,038.48$ & $1,545.91$ & 3.93 & 0.61 & 8.12 \\
\hline & 2015 & $46,942.77$ & $136,396.34$ & $224,347.31$ & 206969.36 & $18,979.33$ & $2,573.92$ & 5.48 & 1.15 & 13.56 \\
\hline
\end{tabular}




\begin{tabular}{|c|c|c|c|c|c|c|c|c|c|c|}
\hline & 2014 & $38,683.41$ & $116,808.85$ & $182,730.94$ & 167491.74 & $16,864.42$ & $2,218.69$ & 5.74 & 1.21 & 13.16 \\
\hline & 2013 & $33,933.36$ & $104,911.26$ & $163,777.74$ & 150509.77 & $14,617.70$ & $1,459.82$ & 4.30 & 0.89 & 9.99 \\
\hline \multirow{5}{*}{$\begin{array}{c}\text { Eastern } \\
\text { Bank } \\
\text { Limited }\end{array}$} & 2017 & 24,361 & 184,027 & 253,365 & 234423.56 & 21,586 & 2,405 & 9.87 & 0.95 & 11.14 \\
\hline & 2016 & 21,449 & 152,084 & 211,185 & $191,545.36$ & 20,572 & 2,656 & 12.38 & 1.26 & 12.91 \\
\hline & 2015 & 23,398 & 130,226 & 189,563 & $170,383.81$ & 20,496 & 2,221 & 9.49 & 1.17 & 10.84 \\
\hline & 2014 & 24,655 & 118,291 & 172,124 & $153,206.03$ & 20,087 & 2,107 & 8.55 & 1.22 & 10.49 \\
\hline & 2013 & 25,904 & 102,910 & 157,882 & $139,604.53$ & 18,450 & 2,568 & 9.91 & 1.63 & 13.92 \\
\hline \multirow{5}{*}{$\begin{array}{c}\text { Mutual } \\
\text { Trust } \\
\text { Bank } \\
\text { Limited }\end{array}$} & 2017 & $24,578.38$ & $145,606.99$ & $201,753.93$ & $189,991.85$ & $11,761.96$ & $1,980.34$ & 8.06 & 0.98 & 16.84 \\
\hline & 2016 & $21,422.84$ & $114,355.76$ & $165,370.69$ & $155,552.30$ & $9,818.26$ & $1,463.59$ & 6.83 & 0.89 & 14.91 \\
\hline & 2015 & 26,210 & 97,589 & $146,059.30$ & $137,129.99$ & $8,929.20$ & 1,366 & 5.21 & 0.94 & 15.30 \\
\hline & 2014 & 20,768 & 77,141 & $116,300.96$ & $109,530.43$ & $6,770.41$ & 961.56 & 4.63 & 0.83 & 14.20 \\
\hline & 2013 & $25,824.40$ & 59,548 & $101,172.55$ & $95,723.39$ & $5,449.06$ & 573.25 & 2.22 & 0.57 & 10.52 \\
\hline \multirow{5}{*}{$\begin{array}{c}\text { NRB } \\
\text { Bank } \\
\text { Limited }\end{array}$} & 2017 & 4,953 & 22,921 & $34,940.08$ & $8,581.56$ & 4669.37 & 442.92 & 8.94 & 1.27 & 9.49 \\
\hline & 2016 & 6,944 & $12,589.37$ & $24,729.83$ & $1,838.96$ & 505.08 & 525.28 & 7.56 & 2.12 & 104.00 \\
\hline & 2015 & 5384.9 & $11,092.41$ & $20,534.62$ & 1,960 & 4478.51 & 236.346 & 4.39 & 1.15 & 5.28 \\
\hline & 2014 & 3519.5 & $6,291.88$ & $13,491.50$ & $1,392.45$ & 3963 & 65.82 & 1.87 & 0.49 & 1.66 \\
\hline & 2013 & 93 & 454 & 5,966 & $1,955.14$ & 4010.83 & 10.26 & 11.03 & 0.17 & 0.26 \\
\hline \multirow{5}{*}{$\begin{array}{c}\text { One Bank } \\
\text { Limited }\end{array}$} & 2017 & 26,144 & 170,393 & 227,202 & 73,062 & 14,109 & 2,181 & 8.34 & 0.96 & 15.46 \\
\hline & 2016 & 28,049 & 132,084 & 188,241 & 70,895 & 12,916 & 2,061 & 7.35 & 1.09 & 15.96 \\
\hline & 2015 & 22,900 & 106,749 & 154,193 & 61,444 & 11,579 & 1,922 & 8.39 & 1.25 & 16.60 \\
\hline & 2014 & 14,724 & 90,499 & 121,820 & 49,787 & 10,225 & 2,096 & 14.24 & 1.72 & 20.50 \\
\hline & 2013 & 10,292 & 76,573 & 102,691 & 44,183 & 8,576 & 1,349 & 13.11 & 1.31 & 15.73 \\
\hline \multirow{5}{*}{$\begin{array}{l}\text { Premier } \\
\text { Bank } \\
\text { Limited }\end{array}$} & 2017 & 23164.7 & 137728.1 & $182,537.05$ & 88148.14 & 13159.01 & 1969.33 & 8.50 & 1.08 & 14.97 \\
\hline & 2016 & 23301.14 & 113,778 & 155,167 & $143,254.04$ & 11913.23 & 1602.05 & 6.88 & 1.03 & 13.45 \\
\hline & 2015 & 24426.39 & 917 & 131,697 & 121033.23 & 131696.9 & 961.55 & 3.94 & 0.73 & 0.73 \\
\hline & 2014 & 10195 & $46,400.57$ & $68,240.34$ & 61963.23 & 6277.11 & 1772.01 & 17.38 & 2.60 & 28.23 \\
\hline & 2013 & 65130.01 & $33,664.58$ & $47,343.23$ & 42705.19 & 638.044 & 1088.31 & 1.67 & 2.30 & 170.57 \\
\hline \multirow{5}{*}{$\begin{array}{c}\text { Prime } \\
\text { Bank } \\
\text { Limited }\end{array}$} & 2017 & $23,807.14$ & 198,323 & 281,275 & $22,087.48$ & $24,707.80$ & 1,059 & 4.45 & 0.38 & 4.29 \\
\hline & 2016 & $48,249.21$ & 170,211 & 256,599 & $16,438.22$ & $25,284.85$ & $2,195.04$ & 4.55 & 0.86 & 8.68 \\
\hline & 2015 & 62,733 & $151,864.53$ & 252,161 & 29,283 & 26,415 & 2,139 & 3.41 & 0.85 & 8.10 \\
\hline & 2014 & 72,642 & $147,366.65$ & 254,912 & 27,313 & 24,461 & 2,393 & 3.29 & 0.94 & 9.78 \\
\hline & 2013 & $56,939.52$ & $153,588.76$ & $256,927.11$ & $23,029.62$ & $23,029.62$ & $1,829.50$ & 3.21 & 0.71 & 7.94 \\
\hline \multirow{5}{*}{$\begin{array}{c}\text { South } \\
\text { East Bank } \\
\text { Limited }\end{array}$} & 2017 & 62,911 & 234,317 & 339,288 & 313,454 & 25,824 & 1,169 & 1.86 & 0.34 & 4.53 \\
\hline & 2016 & 61,732 & 191,866 & 291,798 & 265,264 & 26,524 & 2,435 & 3.94 & 0.83 & 9.18 \\
\hline & 2015 & 58,829 & 168,878 & 260,718 & 198,991 & 27,207 & 3,069 & 5.22 & 1.18 & 11.28 \\
\hline & 2014 & 56,379 & 147,071 & 236,608 & 212,055 & 24,543 & $3,836.94$ & 6.81 & 1.62 & 15.63 \\
\hline & 2013 & 57,589 & 134,864 & 220,931 & 198,991 & 21,929 & 3,379 & 5.87 & 1.53 & 15.41 \\
\hline
\end{tabular}

$--0-$ 